Article

\title{
The Traditionalist Salafis' Perspective and Discourse on Militant Jihād
}

\author{
Mashail Haydar Ali ${ }^{1,2}$ \\ 1 Department for Continuing Education, University of Oxford, Oxford OX1 2JD, UK; \\ mashail.ali@conted.ox.ac.uk \\ 2 Centre for Languages Culture and Communication, Imperial College London, London SW7 2AZ, UK
}

Received: 29 March 2019; Accepted: 23 May 2019; Published: 30 May 2019

\begin{abstract}
This paper argues that the jihādi ideology draws upon the authentic and normative traditionalist salafi epistemology, which provides a moral and theological justification for militant $j i h \bar{a} d$. In the current climate of political unrest and conflicts in the Middle East, maintaining a nexus between jihād and authentic Islam is crucial for traditionalist salafism in pursuit of authority, relevance and political interests. Through the misappropriation of the Meccan-Medinan trajectory and the concepts of nash (abrogation) and 'ijmä' (consensus), the input of salafi scholars and preachers revitalizes the discourse around militant jihāa as a legitimate vehicle for change and consequently propels jihādi ideology forward.
\end{abstract}

Keywords: salafism; jihād; consensus; ijtihād; abrogation

\section{Introduction}

Salafism is a heterogeneous movement (Wagemakers 2016) with rival factions who often compete over the sloganaبو على منهاج النبو "Upon the Prophetic Methodology" in their online literature and social media accounts to legitimize themselves by identifying with the Prophet and his companions.

This paper focuses on the traditionalist salafi faction, or "purist" salafis (Wiktorowicz 2006), which has acquired a substantial following for its authenticity, intellectual consistency, and rooting in Islam's religious tradition. Led by a hierarchy of academically-oriented 'ulama (scholars) (Nielsen 2016), its influence originates from institutional recognition being the state-sponsored religious authority of Saudi Arabia, which is headed by the Kingdom's Grand Mufti. The prominence and international fame of some of its scholars (Nielsen 2016), coupled with the mediatization of religion (Hjarvard 2016), has attracted them a huge following among citizens of other Arab countries.

Previous studies have portrayed the traditionalist salafis as apolitical for a variety of reasons, including their theologically framed discourse, having been co-opted by the Saudi government, and for abstaining from modern methods of political and social organization, concepts, and symbols that are of western origin ${ }^{1}$. Additionally, their online discourse on militant jihād is mainly in Arabic. Therefore, their political activity is not visible, or may not be noticeable, in the modern political sphere. Wiktorowicz (2006, p. 208) referred to them as "purists" whose activities emphasized non-violent methods and focused on "propagation, purification, and education". He suggested that they were "the least likely (of all salafi factions) to support the use of violence" Wiktorowicz (2006, p. 234). Likewise, Hassan (2016, p. 1) described them as "politically submissive", while Olidort (2016) argued that conservative salafism has been misconstrued and erroneously judged as a political concept, whereas,

1 For instance, the late Grand Mufti of Saudi Arabia, Ibn Bāz (1990, p. 27), criticized pan-Arab nationalism as an un-Islamic, infidel, oppressive, and immoral entity. 
in fact, it is a theological one. Olidort added that their publishing activity focused on ritual observance and the theological concepts.

However, close inspection of the traditionalist salafis' publications and fatwas in Arabic reveals that proponents of this perspective are proactive on the media jihād front, and their strategy of the "jihād by tongue and advocacy" (Ibn Bāz n.d.) provides influential scholarly ideas, sermons, and fatwas for justifying and popularizing militant $j i h \bar{a} d$ as a vehicle for change regionally and as an exclusive strategy for dealing with non-Muslims. Further, the mediatization of religion has augmented the prominence and visibility of some of this faction's key players.

There are multiple meanings of the term jihād in the Qurān, but for the purpose of this paper it is used in the narrow sense of "a holy war fought by Muslims against people who are a threat to Islam" (Cambridge Dictionary n.d.), because this is the meaning cited in the traditionalist salafis' literature popularizing militancy. Early Muslim jurists focused their attention on this sense of the word, which subsequently became the predominant meaning of the term (Afsaruddin 2019). The jihädi ideology, then, is a religious-political ideology based on a belief in militant jih $\bar{a} d$ and draws on puritanical sunni Islam or salafism (Jones 2014).

This paper argues that the discourse of traditionalist salafi scholars and preachers on jihad as a holy war and duty on Muslims provides the moral and religious argumentation for militancy through the misappropriation of the Meccan-Medinan Islamic trajectory and the concepts of nash (abrogation) and 'ijm $\bar{a}$ ' (consensus). A recent interview on MBC satellite TV channel with the outspoken former Imam of Mecca's Grand Mosque, Sheikh Al-Kalbāni (2016), demonstrates the impact of this faction's literature on jihāadi groups, such as $D \bar{a}^{*} i s h^{2}$, the so-called Islamic State (ISIS). Al-Kalbāni admitted that the latter's ideology draws on "our own books, from our own principles":

"Dā'ish's ideology is salafi. Their thought is not that of the Muslim Brotherhood, Qutbism, Sufism, or Ash'ari. They draw their ideas from what is written in our own books, from our own principles. Therefore, you find that most of those who criticize it (i.e., among salafi scholars and clerics), they do not criticize its thought; they criticize its actions."

\section{The Importance of the Study}

The importance of this study is two-fold. First, it examines and critiques the discourse and reasoning of some of the prominent traditionalist salafi scholars and preachers on militant jihād. Their sermons and fatwas resonate in that they can radicalize people and mobilize recruits. This study aims to advance understanding of the reasoning of those who promote militancy as a tool for change and an exclusive strategy for dealing with non-Muslims. Second, the study seeks to point out discrepancies between the traditionalist salafis' creed of absolute monotheism and their evidence for justifying militancy. For instance, it will be argued that the misappropriation of the concepts of nash (abrogation) and 'ijmā' (consensus) allows the divine message to be subjugated to the subjective nature of the scholar's discretion and rulings, contrary to the religious tenet that divinity should provide guidance to scholars. This is a pertinent point since it proves a level of pragmatism on the part of the traditionalist salafis in that they do not hesitate in employing methods which have long been criticized by their scholars as un-Islamic. According to Wiktorowicz (2006), this faction criticizes its rivals as rationalists who select the most suitable strategies for achieving their political ambitions and then misappropriate religious evidence to support their goals. The study will conclude that traditionalist salafis scale down the Prophetic methodology through the process of abrogation under the pretext of uniformity with the consensus of early Muslim scholars, to propel the jihāali ideology.

$2 D \bar{a}^{\prime} i s h$ is a pejorative Arabic name for ISIS. 


\section{Materials and Methods}

The discussion below will examine some of the online publications and fatwas of a small number of acclaimed traditionalist salafi scholars and preachers who enjoy authority and write on jihād either voluntarily, in an official capacity, or in response to queries from followers. The scholars and preachers fall into two groups:

(1) Those who are employed by the government, are academically-oriented and occupy positions of authority within the religious or academic hierarchy, such as the late and much revered Sheikh 'Abd al-'Aziz Ibn Bāz, the former Grand Mufti of Saudi Arabia (1993-1999), Al-Fawzān, Sālih (n.d.), member of the Saudi Council of Senior Scholars and the Permanent Committee for Islamic Research and Ifta', and the Yemini scholar Muhammad Al-Mawlid Al-'Ansi, who publishes articles on the Association of Yemeni Scholars' website and online newspapers; and

(2) Volunteer preachers who have followers and exercise their authority online through mass media, e.g., by interacting with followers through a website.

The data has been collected from official, professional, and personal websites, and it is broadly representative of the collective opinion of this faction for two reasons. First, the authors of the fatwas are distinguished religious figures who are well known for their expertise and orientation. Second, traditionalist salafism adopts a set of strict rules for generating religious opinions to ensure that rulings are meticulous, methodically sound, and based on textual evidence from Islam's primary sources and the consensus of the prophet's companions (Wiktorowicz 2006; Lauzieri 2010). These rules act as safeguards for intellectual consistency.

The research starts with an overview of the salafi movement, its creed, and main rival factions. After a brief description of traditionalist salafism and its key characteristics, the Meccan-Medinan trajectory will be discussed as the backdrop for the misappropriation of the concepts of "abrogation" and "consensus". The next section will focus on the argumentation for jihad as presented by Ibn Bāz (n.d.) to pinpoint how abrogation and consensus are misappropriated to justify and propel the jihādi ideology. The final section will explore the traditionalist salafis' online discourse on jihad explaining its types, terms, and conditions, as well as rewards, with the aim of framing jihād as the Muslim's profitable duty and not just for defense. Finally, the conclusion will sum up the findings.

\section{The Salafi Spectrum}

Lauzieri (2010) provided an elaborate examination and evaluation of the multiple layers of meaning that have been attached to the word salafism, or salafiyya in Arabic, and its historicity. Essentially, it is a term that sunni puritans use to refer to their rigorous methodology, strict interpretation of monotheism, and literal adherence to Islam's primary sources Lauzieri (2010). As a spectrum of factions, salafism seek to widen the scope of what they consider as un-Islamic innovation and restrict the range of permitted Islamic practices. Salafi factions generally hold a puritanical approach to Islam by following the Qurān, replicating the model of Prophet Muhammad (i.e., the Sunnah), and citing the guidance of the Prophet's companions, whom they refer to as the pious ancestors ("al-salaf al-salih") for having learned about Islam directly from the Prophet and subsequently provided an accurate account of the Prophetic model (Wiktorowicz 2006, p. 207).

Despite their differences in strategy, salafi factions share a common 'aqidah (creed) and the goal of establishing an Islamic state or order, in which religion and government are united, and the shar $\vec{\imath} a h$ law is enforced as a comprehensive way of life. While salafi jurisprudence draws strictly on the Qurān and sunnah, it also seeks clarifications from the 'ijm $\bar{a}$ ', i.e., the consensus of the righteous salaf (Esposito n.d.), including the "scholars of guidance" among the initial three generations of Islam. Since the Qurān mentions God as the supreme legislator, it follows that humans are obligated to follow His Shari'a law in its entirety, according to salafis. Humans cannot and should not legislate, as this power is reserved for God (Allah) alone (Wiktorowicz 2006). To eliminate the potential of human bias, speculation, subjectivity, and error in religious rulings, salafi scholars follow rigorous and 
long established methods and rules for generating opinion to ensure that findings are based solely on authentic primary evidence (Wagemakers 2016; Wiktorowicz 2006). This point is so central to salafis that traditionalist salafis often criticize rival salafi factions, such as political Islamists and the jihādis, as rationalists who first select the most suitable strategies for achieving political ambitions and then misappropriate religious evidence to support their goals. Despite accusing their rivals of this impropriety, they themselves act in a similar way by misappropriating texts and the concepts of nash (abrogation) and ' $i j m \bar{a}$ ' (consensus) to justify and promote militant jihād. All salafi groups show and encourage acts of resistance, by word or deed, when motivated by a sense of external danger or threat from secularism, and through their rivalry and attempt to outdo each other, they contribute to the development and consolidation of online literature on violent $j i h \bar{a} d$.

In a detailed examination of the anatomy of the salafi movement, Wiktorowicz's (2006) identified three major groups within the salafi movement: the purists (i.e., the traditionalist salafis), the politicos (i.e., political Islamists, e.g., the Muslim Brotherhood), and the jihādis (such as the $A l-Q \bar{a} \cdot i d a$ organization and the Islamic State, which is usually referred to by the acronym ISIS). Salafi factions differ in their leadership styles, political methods, social organization, and territories. Likewise, each faction may be more or less oriented towards elitism, violence, intellectual consistency, and revolutionary attitudes. Nonetheless, receiving the same teaching, relying on the same primary sources of Islam, and sharing the 'aqidah (creed) and goal can potentially lead to inter-group interaction, influence, and fluidity in perspectives. At times, differences between individuals or groups may fade away, or individuals may defect or change their loyalty or manhaj (strategy) over time.

\section{Traditionalist salafism}

This faction focuses on emulating (taqlìd) the actions and behaviors of the al-salaf al- șâlih, i.e., "the pious ancestors" ${ }^{3}$, in a consistent and meticulous way (Wagemakers 2016). Traditionalist salafism promotes a literal and exclusivist interpretation of the Qurān, the Prophetic sunnah and Islamic law (Saada 2018). Its followers criticize the modern oppositional and revolutionary methods enacted by other salafi factions, e.g., political Islamists, as being at odds with the Prophetic sunnah and the consensus of the righteous salaf (Wiktorowicz 2006). They portray modern political activism and organization as not only un-Islamic, but also a type of innovative deviancy. For instance, Sheikh Sālih al-Fawzān, member of the Saudi Council of Senior Scholars and the Permanent Committee for Islamic Research and Ifta', denounced activities such as demonstrations and sit-ins as un-Islamic:

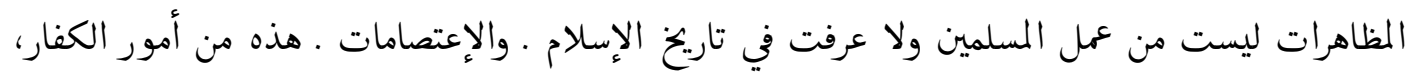

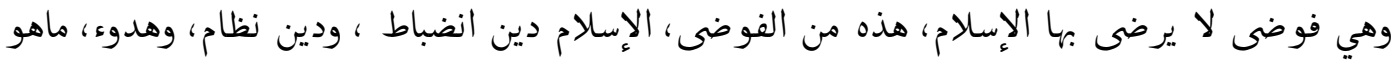

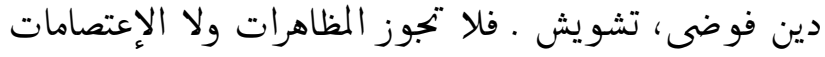

"Demonstrations are not the work of Muslims and are not known in the history of Islam. And sit-ins. These are acts of infidels. They are disorder which Islam does not accept. These (acts) are chaos. Islam is a religion of discipline, a religion of order, and tranquility. It is not a religion of chaos and confusion. So demonstrations and sit-ins are not allowed."

Another salafi authority, the late scholar Sheikh Muhammad Nāsir Al-Dīn Al-Albāni (2004) criticized the Muslim Brotherhood over their concern with modern oppositional politics at the expense of scholarship and education saying:

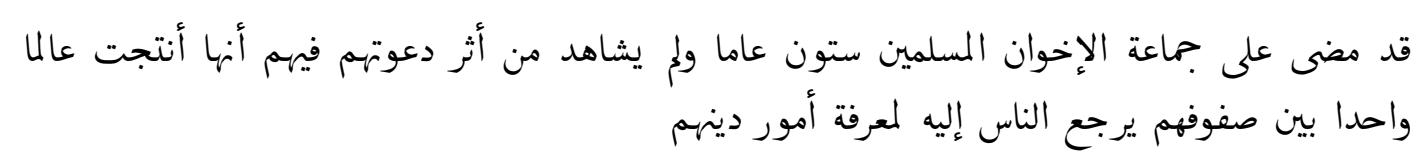

3 This is a reference to the Prophet's companions and the first three generation of Muslims (Cummins 2017). 
"Sixty years have passed since the Muslim Brotherhood Group was formed, and, in considering the impact of the group's thought upon themselves, there has not been a single scholar among their ranks that people can consult with to learn about the affairs of their religion."

Al-Albāni advised his followers ثقف ثم كتل ("educate, then group"), suggesting a sequence of steps towards establishing an Islamic state-education through religious propagation and then grouping to finally realize an Islamic state.

The leadership of the 'ulama has bestowed upon this faction an aura of expert knowledge and authority. For instance, The Council of Senior Scholars (majlis hay'at kibar al-'ulama - مجلس هيئة كبار العلماء) is Saudi Arabia's highest religious authority and acts as an advisory body for the King on religious matters (Bligh 1985), while the Permanent Committee for Scholarly Research and Ifta' اللجنة الدائمة للبحوث العلمية والإفتاء jurisprudence. Their point of reference for interpreting the Qurān and the Prophetic sunnah (tradition) are the understanding and interpretations of medieval scholars, such as Ibn Taymiyyah and Ibn Al-Qayyim, as well as nineteenth century Hanbali-Wahhabism (Wagemakers 2016). This subservience to the opinions of scholars of the past authenticates the traditionalist salafi's rulings, on the one hand, but it also contains and limits their perspective on contemporary political and global issues.

Proponents of this salafi branch discuss and propagate militant jihād, which Ibn Bāz (n.d.) called the "Jihäd by hand", as a suitable strategy in the right time and circumstance, but they refer to their current manhaj as the "Jihād with the tongue and advocacy". From this perspective, the current situation is not yet conducive for an all-out jihād by hand (Ibn Bāz n.d.) because the political climate is analogous to the Meccan period of early Islamic history, when Muslims were a minority amidst hostile and authoritative non-Muslim tribes (Wiktorowicz 2006). They portray themselves as followers of the Prophetic model of the first thirteen years of Islam, when peaceful means of propagation were used for teaching Islam, capacity building, and advising hostile tribal leaders in a diplomatic and considerate way, despite advocating the abrogation of the verses which instructed the Prophet (PBUH) to act in this way. Abrogation is justified by reference to what they present as a binding uniformity with the consensus of the scholars of the past and the pious ancestors.

Nonetheless, and in response to the growing influence and criticism from political Islamists since the nineties, this faction has gradually re-positioned its stance, and, as stated by Hassan (2016), it has become more politicized. It must be emphasized though that its political practice remains essentially based on theological grounds. For instance, the Saudi Council of Senior Scholars has issued, in recent years, online fatwas calling for jihād against heads of states, such as Al-Gaddāfi of Libya (Al-Khamīs 2011) and Al-Assad of Syria (Alkhaleejonline 2015, October 6). The carefully worded and substantiated fatwas shifted the discourse around the "Arab Spring" from one of quest for liberty to one of religious jihād. Also, the reference to their manhaj as "jihād with the tongue and advocacy" appears to be intentional to connote pro-activity in the face of what Nielsen (2016) described as online mockery and scorn directed at traditional Islamic authorities for having been perceived as out of touch with modern political realities.

\section{The Meccan-Medinan Trajectory}

So, at what point during the revelation of the Qurān did the concept of militant Jihād develop? The Qurān was revealed to Prophet Muhammad gradually over a period of approximately 23 years (Islam Q\&A 2012), a fact which has been mentioned in the Book:

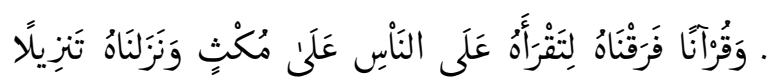

"And (it is) a Qur'an which We have separated (by intervals) that you might recite it to the people over a prolonged period. And We have sent it down progressively."

(The Noble Qurān n.d., 17: 106) 
There are 114 sürahs (chapters) in the Qurān: the chronologically earlier 86 of them are referred to as "Meccan", because they were revealed in Mecca prior to the Prophet's and his companions' hijra (migration) to Medina to establish the first Islamic state. The other 28 sürahs are called "Medinan", because they were revealed after the hijra to Medina. Despite a minor controversy around where exactly the line should be drawn between the Meccan and Medinan sürahs, this does not impact on the overall trajectory in terms of the themes and temporal order of the sürahs. That the concept of jihīd developed in the latter part of the trajectory, i.e., during the Medinan period, when the Prophet ruled over the first Islamic state, has not been in question.

Thematically, the Meccan sürahs (chapters) focus on propagation, the 'aqìdah (creed) and 'uṣul al-din (the fundamentals of the religion), as they were addressed to the people of Mecca while Muslims were a minority. The Medinan sūrahs, which were addressed to the people of Medina post-hijra, focus on shar $\vec{i} a h$ rules for running the affairs of the first Islamic state, promote jihād as a vehicle for spreading Islam, and mention the hudūd (legal boundaries) penalties. Al-Khudairi, Muhammad (n.d.), a salafi preacher on the website "alsalafway", draws the following thematic distinction between the Meccan and Medinan Sürahs:

"The fundamentals of the religion, including commands and prohibitions, are mentioned in the Meccan sürahs, but the details of these laws and provisions relating to transactions, marriages, preparations for war, sales, hudud (penalties), and others, these are hardly mentioned in the Meccan sürahs; rather they are mentioned in the Medinan sürahs."

Al-Munajjid (2008), the founder of "Islam Q\&A" website, agrees that the Medinan sūrahs are characterized by the abundance of verses which mention jih $\bar{a} d$ and its provisions. Though he gives a detailed religious opinion on the topic, there is very little reference to the social and political milieu of the Medinan society which encouraged war. At a time when there was a neat coincidence between territorial boundaries and religious beliefs, war became a vehicle for countering rivalry and hostility. When considered in its entirety, the Meccan-Medinan trajectory displays a temporal order of an evolving, versatile, and context-driven Prophetic methodology (or strategy), ranging from diplomacy and tolerance in Mecca to waging war and jihād in Medina.

To sum up, the trajectory presents a diverse Prophetic strategy for peace and war. So how do the concepts of abrogation (nash) and consensus ('ijmma') provide a leeway for traditionalist salafi scholars and preachers to justify jih $\bar{a} d$ as an exclusive international relations strategy for dealing with non-Muslims (or those they classify as such)?

\section{Al-Nash (Abrogation)}

In the Islamic legal exegesis, nash is a process whereby a more recent Qurānic verse supersedes or repeals another when both deal with the same topic but may appear to be inconsistent or contradictory. The abrogating text is called nassih (the active participle of the verb nasaha) and the abrogated one is mansū $\underline{h}$ (the passive participle). Nas $\underline{h}$ is restricted to the ahkām (provisions) relating to the commands and prohibitions of the shar $\vec{\imath}$ ah. It does not apply to creed and beliefs (Islam Q\&A 2015).

Nash took place and was implemented in a very restricted way when the Qurān was being revealed. It has been mentioned in few verses as a way for providing context-specific and gradual guidance to the Prophet and his companions in the interest of Muslims (Islamweb 2002):

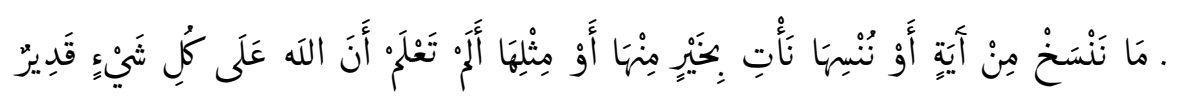

"We do not abrogate a verse or cause it to be forgotten except that We bring forth (one) better than it or similar to it. Do you not know that Allah is over all things competent?" (The Noble Qurān n.d., 2: 106)

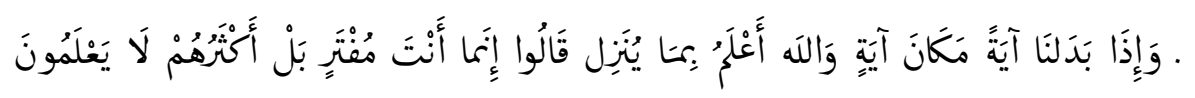


"And when We substitute a verse in place of a verse—and Allah is most knowing of what He sends down—they say, "You, (O Muhammad), are but an inventor (of lies)." But most of them do not know." (The Noble Qurān n.d., 16: 101)

The first abrogated text in the Qurān changed the way Muslims prayed. The Prophet was initially commanded that Muslims should face Jerusalem in their prayer, but then he was instructed to face Mecca instead (Islamweb 2016):

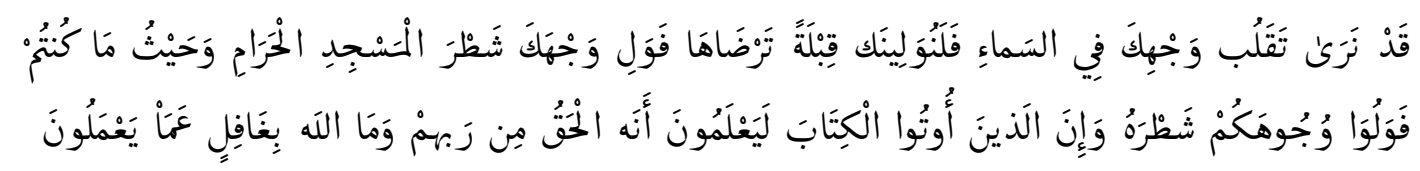

"We have certainly seen the turning of your face, (O Muhammad), toward the heaven, and We will surely turn you to a qiblah with which you will be pleased. So turn your face toward al-Masjid al-Haram. And wherever you (believers) are, turn your faces toward it (in prayer)." (The Noble Qurān n.d., 2: 144)

In the absence of any text from Islam's primary sources giving authority to clerics, scholars or "ancestors" to repeal verses at their own will, there have been different opinions and disputes over the scope of the abrogated texts (Bedgali et al. 2017; Islam Q\&A 2015). Some jurists have resorted to abrogation when they stumbled on apparently contradicting texts which they were unable to reconcile. This, however, does not mean that the same texts cannot be reconciled by another jurist. The divergent rulings of scholars on the number and scale of the abrogated texts are a consequence of the fact that they are subject to scholars' ijtihād, i.e., "independent analogical reasoning" (Esposito n.d.). A jurist may perceive texts as contradictory or mutually exclusive, while another jurist may find that a complementary relationship is discernible.

Some scholars have justified abrogation by reference to the fact that the Qurān was revealed over a period of more than two decades, and therefore new rulings were needed to meet the changing circumstances of Muslims (Islam Q\&A 2015). They implicitly accept that there are contradictory texts in the Qurān. A staunch opponent of abrogation, Al-Banna (2011), argued that it is erroneous to accept the rule of recency or a change of circumstance as reasons for abrogating verses just because these were the grounds used by some early Muslim scholars. If such flimsy reasons are permissible for repealing divine texts, then the process would have to continue on to the present day to customize the texts to the new needs and circumstances of Muslims around the world. Al-Banna also raises the concern that as the Qurān is the word of God, does abrogation mean that, initially, God made mistakes by revealing the abrogated texts, then He corrected Himself by revealing the more recent abrogating verses? Abrogation raises serious questions as to whether the divine message is subservient to the rulings of scholars and their political agendas, or whether divinity should provide guidance to scholars. It reverses the power relationship between divinity and humans by allowing scholars to exercise authority over the divine message by firstly using their own logic and ijtihād (opinion) to decide which verses are contradictory from their own perspective, and secondly, prioritizing and declaring some of the texts as void. This means that scholars, who are supposed to be guided and guide others by the teachings of the Qurān, are at liberty to pass judgment and make corrections to the divine message. This practice is at odds with the traditionalist salafis' creed, which advocates absolute adherence to the concept of tawhīd (monotheism) and ardent rejection of the role of human logic, subjectivity, and speculation (Wiktorowicz 2006). In an answer to the question "what is Islam?", Ibn Bāz, 'Abd al-'Aziz (n.d.) replied:

$$
\begin{aligned}
& \text { الإسلام: هو الاستسلام لله والخضوع له بفعل أو امرهوترك نو اهيه، هذا هو الإسلام .... الإسلام يعني: الانقياد والذل لله بتوحيده والإخلاص له، }
\end{aligned}
$$

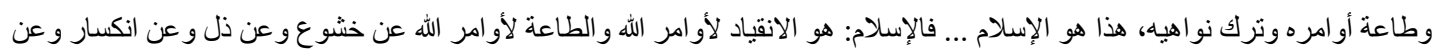

$$
\begin{aligned}
& \text { رغبة فيما عند الله مرضاة لله. نعم. }
\end{aligned}
$$

"Islam is the submission to God and surrendering to him by acting on his orders and leaving his prohibitions; this is Islam ... Islam means the subordination and subjugation (of humans) to God 
by accepting His unity and being sincere to him, obeying his orders, and keeping away from his prohibitions, this is Islam ... so Islam is being led by God's orders and obeying His orders out of submissiveness, humbleness, humility, and a desire to satisfy Him. Yes."

The first Muslim exegete to deny abrogation was Abū Muslim Al-Ișfahānī (868-934), a prominent figure during the 'Abbāsid dynasty. His books are no longer available but his arguments were mentioned by his contemporaries who criticized him (Bedgali et al. 2017). Al-Iṣfahānī accepted that some verses were abrogated during the Prophet's life, such as changing the Muslims' direction during prayer, but he insisted that abrogation ended with the Prophet's life. He relied on this verse:

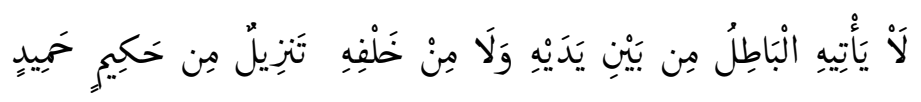

"Falsehood cannot approach it from before it or from behind it; (it is) a revelation from a (Lord who is) Wise and Praiseworthy." (The Noble Qurān n.d., 41: 42)

Al-Iṣfahānī argued that abrogation amounted to ascribing falsehood to Qurānic texts, whereas the Qurān embodied i'jaz (inimitability), a key quality which, according to Muslims, authenticates the Prophetic status of Muhammad (PBUH) by eliminating doubts about its possible composition by a human being. This characteristic of the Qurān, which all Muslims hold to be true, means that it is free of any deficiency, flaw, or distortion to require the abrogation of verses by those who were supposed to be guided by it.

In an article entitled 'Quranic I'jāz', the Saudi Minister of Islamic Affairs Sheikh Salih Al Al-Sheikh (2009) pointed out the importance of $i^{\prime} j \bar{a} z$ in authenticating the prophethood because it provides evidence of the superiority of God's word in comparison with human speech:

$$
\begin{aligned}
& \text { كون القرآن معجزا ودليلا على صحة نبوة محمد عليه الصلاة والسلام، وأنه منزل من عند الله، ومن جهة } \\
& \text { أخرى لها صلة بمبحث كلام الله جل وعلا وهو أن القرآن لا يشبه كلام البشر وأن كلام الله جل وعل وعلا } \\
& \text { ليس ككلام البشر }
\end{aligned}
$$

"Being inimitable, the Quran is evidence of the truth of Muhammad's (PBUH) Prophetic status and that it (the Qurān) has been revealed by God. On the other hand, it (I'jaz) relates to the study of the word of God, the Almighty, in that the Quran is not similar to human speech, and God's speech is not like that of humans."

If the Qurān embodies God's perfection, it does not make sense that its verses should be subjected to the scrutiny and opinions of scholars who lack God's qualities. Abrogation hands power to scholars by allowing them to rule on which verses should remain valid or be declared void. Further, Ibn Bāz's definition of Islam as surrendering to God's orders with humility, humbleness, and submissiveness does not tally with the act of repealing parts of His orders.

As far as the concept of jih $\bar{a} d$ is concerned, limiting the scope of abrogation reconciles both parts of the Islamic trajectory, the peaceful Meccan and the jihādi Medinan, in a complementary relationship to form a multi-faceted and sophisticated strategy for peace and war with a spectrum of alternative responses in dealing with non-Muslims in various contexts. This constitutes the only complete and authentic Prophetic methodology. Widening the scope of abrogation, on the other hand, would repeal the earlier verses which commanded forgiveness and cessation of fighting against those who do not fight Muslims and would subsequently limit the purpose of the Muslims' existence in the world to fighting non-Muslims.

The traditionalist salafis' view on abrogation is based on the legacy of medieval scholars (Islam Q\&A 2015; Ibn Bāz n.d.) who seem to have been generous on abrogation. The late former Grand Mufti of Saudi Arabia (between 1993-99), Ibn Bāz (n.d.), ruled that the Medinan "verse of the sword" (The Noble Qurān n.d., 9: 5) had superseded the earlier verses which commanded kindness, patience, and forgiveness. This ruling has been passed down to the traditionalist salafis, which they appear to have embraced opportunistically under the pretext of deference to the opinions of scholars of the past. 


\section{The Argumentation for Jihād}

So how did the concept of jihād crystallize through the Meccan-Medinan trajectory? In an article entitled "Jihād is Not Only for Defense", Ibn Bāz (n.d.) stated that in the earlier Meccan period, God instructed the Prophet to invite people to Islam and argue with good words and kindness, as conveyed by the following verses:

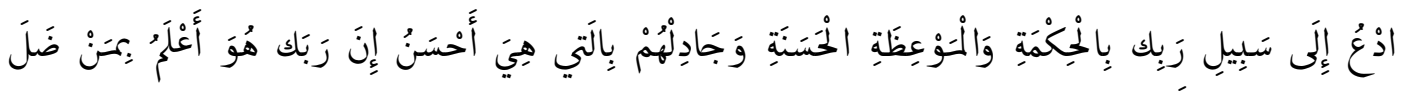

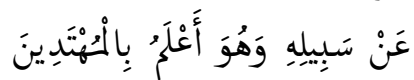

"Invite to the way of your Lord with wisdom and good instruction, and argue with them in a way that is best. Indeed, your Lord is most knowing of who has strayed from His way, and He is most knowing of who is (rightly) guided." (The Noble Qurān n.d., 16: 125)

"Forgive with gracious forgiveness." (The Noble Qurān n.d., 15: 85)

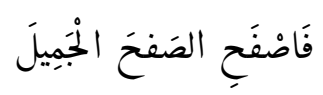

$$
\text { وَاضْبِرْ عَلَى مَا يَقُولُونَ وَاهْجُرْهُمْ هَجْرَا حَمِيلًا }
$$

"And be patient over what they say and avoid them with gracious avoidance." (The Noble Qurān n.d., 73: 10)

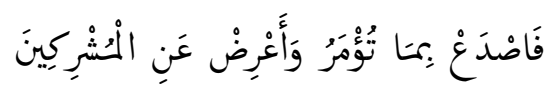

"Then declare what you are commanded and turn away from the polytheists." (The Noble Qurān n.d., 15: 94)

Such verses, which instructed the Prophet to forgive, be patient, and turn away from hostile Meccan tribes, were necessary at that stage, according to Ibn Bāz (n.d.), as the circumstances were not favorable for fighting:

"Because the number of Muslims was small and their many enemies had authority and power, it was the wisdom of God to prevent his messenger and Meccan Muslims from the jihäd by hand, and he ordered them to suffice Jihād with the tongue and advocacy."

After the Prophet and early Muslims migrated to Medina and settled there, the Medinan Sürahs started to be revealed. Ibn Bāz pointed out that these Sūrahs gradually developed militant Jihād into a duty on Muslims. Initially, God gave the Prophet permission to wage jihād because Muslims were oppressed:

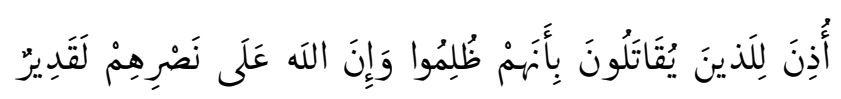

"Permission (to fight) has been given to those who are being fought, because they were wronged. And indeed, Allah is competent to give them victory." (The Noble Qurān n.d., 22: 39)

Then, fighting Jihād became compulsory for Muslims:

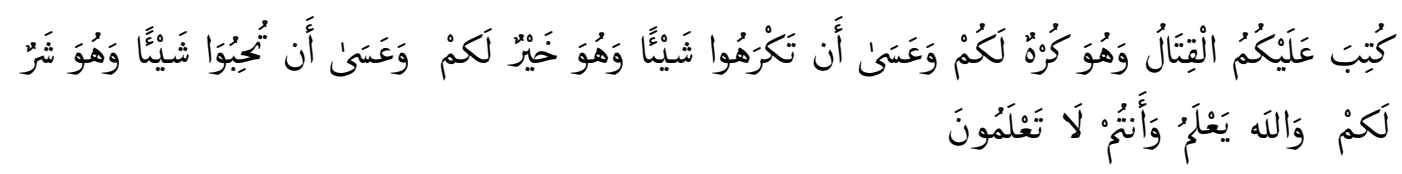

"Fighting has been enjoined upon you while it is hateful to you. But perhaps you hate a thing and it is good for you; and perhaps you love a thing and it is bad for you. And Allah Knows, while you know not ${ }^{4}$." (The Noble Qurān n.d., 2: 216)

4 Abū Bakr Al-Baghdādī, the Caliph of ISIS, quoted this verse in his sermon at Mosul Grand Mosque on 4 July 2014, to remind Muslims of their duty to commit to Jihād (Al-Baghdādī 2014). Al-Baghdādi's sermon was transmitted by Aljazeera.net (2014) and is available at: http://www.aljazeera.net/news/arabic/2014/7/5/ أبو -بكر -البغدادي-يخطب_الجمعة-بالموصل-ويطلب_طاعته 
Afterwards, God commanded the Prophet to fight those who fought Muslims and leave off those who did not:

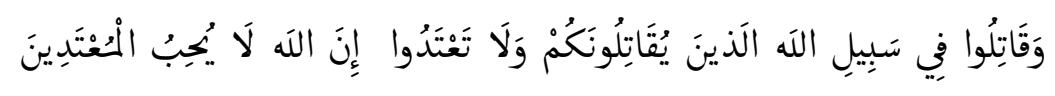

"Fight in the way of Allah those who fight you but do not transgress. Indeed. Allah does not like transgressors." (The Noble Qurān n.d., 2: 190)

Ibn Bāz said that "many of the revealed verses (during the Medinan period) included Jihād, and the Almighty incited (Muslims) on it, and commanded it in his great Book and in the words of his Prophet, peace be upon him."

The verses below made Jihād a duty upon Muslims, says Ibn Bāz (n.d.):

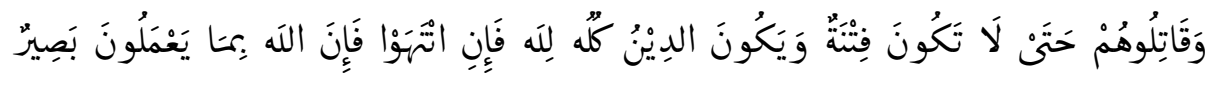

"And fight them until there is no fitnah (discord) and (until) the religion, all of it, is for Allah. And if they cease—then indeed, Allah is seeing of what they do $0^{5}$." (The Noble Qurān n.d., 8: 39)

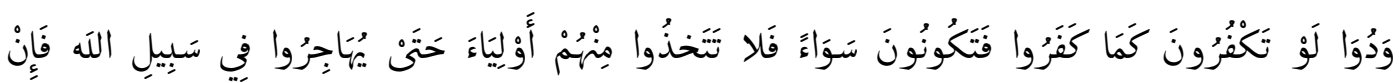

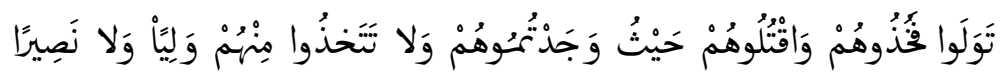

"They wish you would disbelieve as they disbelieved so you would be alike. So do not take from among them allies until they emigrate for the cause of Allah. But if they turn away, then seize them and kill them wherever you find them and take not from among them any ally or helper." (The Noble Qurān n.d., 4: 89)

Then, "the verse of the sword was revealed" to supersede all the former verses that commanded forgiveness and making peace with those who did not fight Muslims. "Muslim scholars", a reference to medieval and subsequent scholars, were cited by Ibn Bāz (n.d.) to have said:

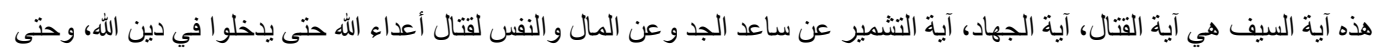

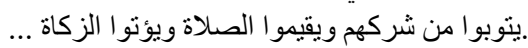

"This is the verse of the sword, it is the verse of Jihad, the verse of getting down to work seriously, (and dedicating) money and the self to fight God's enemies until they enter into God's religion, repent from their polytheism, pray regularly, and give zakat."

The text of the verse of the sword is as follows:

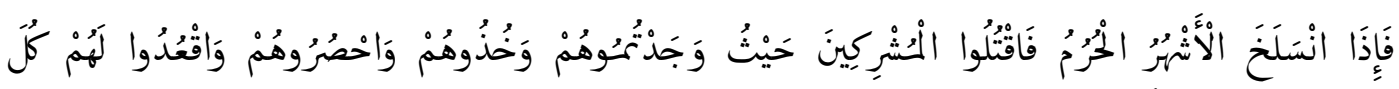

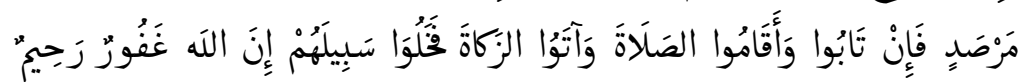

"And when the sacred months have passed, then kill the polytheists wherever you find them and capture them and besiege them and sit in wait for them at every place of ambush. But if they should repent, establish prayer, and give zakah, let them (go) on their way. Indeed, Allah is Forgiving and Merciful."

(The Noble Qurān n.d., 9: 5)

Ibn Bāz mentioned other Qurānic verses which deal with fighting different non-Muslim groups without mentioning the word jihād, to further substantiate his arguments. For instance, he said that advice on the treatment of dhimmis or "'ahl al-Kitaab" ("the people of the Scripture", i.e., Jews and Christians), in the battlefield and afterwards, was given in the following verse:

5 This verse too was quoted by Al-Baghdādī in his exhortation for Jihād during his first speech in the city of Mosul on 4 July 2014 (Al-Baghdādī 2014). 


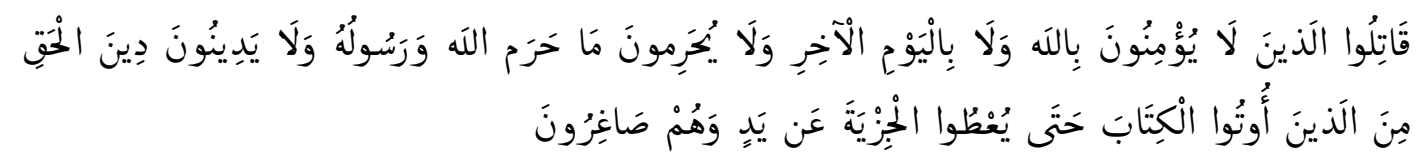

"Fight those who do not believe in Allah or in the Last Day and who do not consider unlawful what Allah and His Messenger have made unlawful and who do not adopt the religion of truth from those who were given the Scripture-(fight) until they give the jizyah willingly while they are humbled."

(The Noble Qurān n.d., 9: 29)

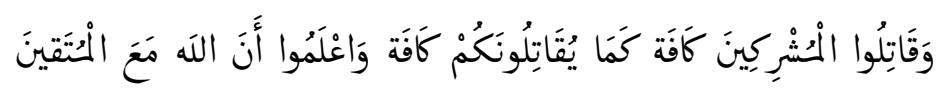

"And fight against the disbelievers collectively as they fight against you collectively. And know that Allah is with the righteous (who fear Him)." (The Noble Qurān n.d., 9: 36)

Ibn Bāz suggested that the above verses marked a new stage in the fight against the "infidels", stating:

"That the infidels should not be left off, unless they repent of their kufr (infidelity) and return to the religion of Allah and adhere to the law of Allah....' 'As for the people of the Scripture (Christians and Jews), if they pay the jizya (tax) willingly while they are humbled, then we leave them off. As for others, it has to be Islam or the sword."

He concludes that should Muslims become powerful and gain authority and standing in the world, the verse of the sword would be put into practice. However, if Muslims become weak and unable to fight all, then it is acceptable to fight according to their ability and leave off those who leave them off, if they can (Ibn Bāz n.d.). It is, however, important to point out that the word "sword" has never been mentioned in the Quran, and it was only at a later stage of the Islamic history that the said "verse of the sword" was named as such by jurists.

Ibn Bāz's argumentation on militant Jihād draws on what he called the consensus of the righteous salaf and Muslim scholars, which, in effect, sets a precedent. While the consensus on jihäd and the abrogating effect of the verse of the sword have been reached through the ijtihäd of scholars of the past, further ijtihād is not allowed by traditionalist salafi scholars once a consensus has been established (Esposito n.d.). As succeeding scholars agree with their esteemed predecessors, the accumulation of their consistent opinions forms a consensus which cannot be challenged. While the ijtihād of medieval scholars over the issue of abrogation demonstrates the exercise of scholarly authority over the divine texts, the scholars' own ijtihād, or opinion, has become so entrenched that it cannot be challenged. It follows that the traditionalist salafis' understanding of the divine texts has to pass through, and is constrained by, the rulings of early Muslim scholars. This constitutes another insurmountable procedural hurdle that gives permanence to the ruling of the scholars of the past on jihād.

The early scholars' opinions on abrogation were informed by testimonies from the Prophet's companions, who were not infallible. Al-Banna (2011) argues that the Prophet's companions and the ancestors could have used their discretion, made an error of judgement, or overlooked details in reporting an event. He adds that jurists have estimated the number of abrogated texts at between 565 and 66 verses, which is testimony of the fact that abrogation is merely a matter of opinion. Further, when the Qurān was being revealed, there were occasions when the Prophet asked his companions to add newly revealed verses in specific places within existing sürahs. Al-Banna contends that there were two verses $(9: 128,129)$ which the Prophet asked his companions to add at a later date to the same sürah containing the verse of the sword. The text for verses 127, 128, and 129, of Surah 9, is cited below to shed some light on the context and meaning: 


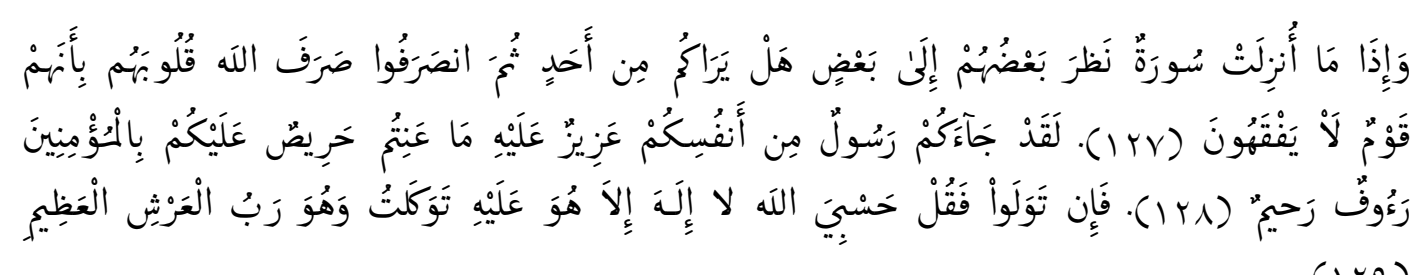

$(1,9)$

"And whenever a surah is revealed, they look at each other, (saying), 'Does anyone see you (if you walked away)?' and then they dismiss themselves. Allah has dismissed their hearts because they are a people who do not understand (127). There has certainly come to you a Messenger from among yourselves. Grievous to him is what you suffer; (he is) concerned over you and to the believers is kind and merciful (128). But if they turn away, (O Muhammad), say, 'Sufficient for me is Allah; there is no deity except Him. On Him I have relied, and He is the Lord of the Great Throne'." (The Noble Qurān n.d., 9: 127-29)

Should abrogation stand and the rule of recency apply, it is legitimate to argue that the revelation of the above verses after the verse of the sword was for the purpose of abrogating the latter (Al-Banna 2011).

\section{Online Discourse on Jihād}

Traditionalist salafis enthusiastically discuss militant jihād online: its types, terms, and conditions, rewards, and how it was and should be practiced. Preachers, scholars, and religious elites alike contribute to the revitalization of contemporary Islamic discourse on jihād. For example, Al-'Ansi (2017), a Yemeni salafi scholar, published an article on the website of the Association of Yemeni Scholars entitled: الجهاد في سبيل الله تجارة المؤمن الرإحة (Jihād on God's path is a Muslim's Profitable Trade), in which he quoted verse 111 of "the Repentance" sürah:

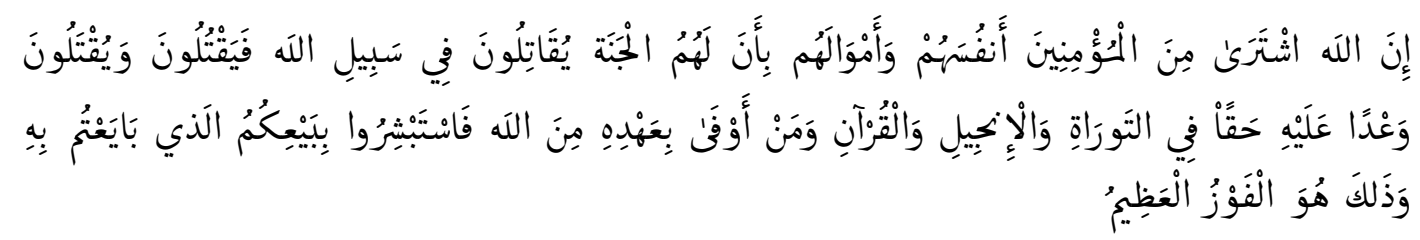

"Indeed, Allah has purchased from the believers their lives and their properties (in exchange) for that they will have Paradise. They fight in the cause of Allah, so they kill and are killed. (It is) a true promise (binding) upon Him in the Torah and the Gospel and the Qur'an. And who is truer to his covenant than Allah? So rejoice in your transaction which you have contracted. And it is that which is the great attainment." (The Noble Qurān n.d., 9: 111)

Al-'Ansi argued that the verse included a transactional contract between God and the believer - God is the buyer, the believer is the seller, the goods are the self and own property, and the price or reward is paradise. The procedure or process - for the delivery of the goods, and then receiving the price-is jihād on God's path. Jihād, for Al-'Ansi, is tantamount to the actual handover between the parties involved in the transaction, which is achieved through "they kill and are killed". There is nothing in between the seller (the Mujāhid) and the price (paradise), other than to be killed, Al-'Ansi asserts. This interpretation seems to incite Muslims to take to jihād without necessarily being in a situation requiring self-defense, and a reward is promised in return. The verse is presented to followers out of context as though it were an instruction from an operations manual. It suggests that Jihād is a default activity of the Muslims' existence, due to a pre-destined transaction with God committing them to killing or being killed.

Al-Najdiy (2012), a preacher who publishes on the salafi website "ahlalhadeeth", identified two types of jihād: the "Seeking [the infidels] jihād", a reference to offensive jihād for the purpose of spreading Islam, and the "Defense jihad", which is waged in response to an external attack. In an article entitled "Motives for the Seeking jih $\bar{a} d$ and the Justification for Killing the Kuffar and Fighting Them", he advises on the circumstances permitting Muslims to initiate the Seeking jihād: 


$$
\begin{aligned}
& \text { فالدافع المبيح لتحرك المسلمين فيما إذا وجدت عندهم القدرقلجهاد الطلب هو وجود الكيانات الكافرة }
\end{aligned}
$$

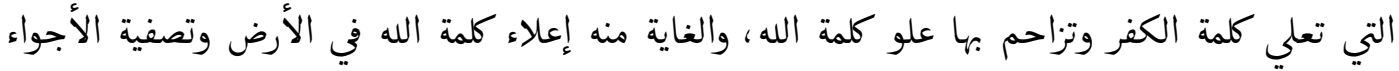

$$
\begin{aligned}
& \text { من كل ما يحول دون انتشار دعوة الإسلام بين العالمين }
\end{aligned}
$$

"The motive that permits the Muslims' move-if they have the ability—to fight the Seeking (of the polytheists) jihäd is the existence of infidel entities that raise the word of infidelity to compete with the prominence of Allah's word, and its purpose is to uphold Allah's word on earth and to clear the atmosphere of everything that prevents the spread of Islam in the universe."

In response to the question "is jihād compulsory in the present time?", Sheikh Ṣalih Al-Fawzān said (Quoted in Ajurry.com; Al-Fawzān 2010):

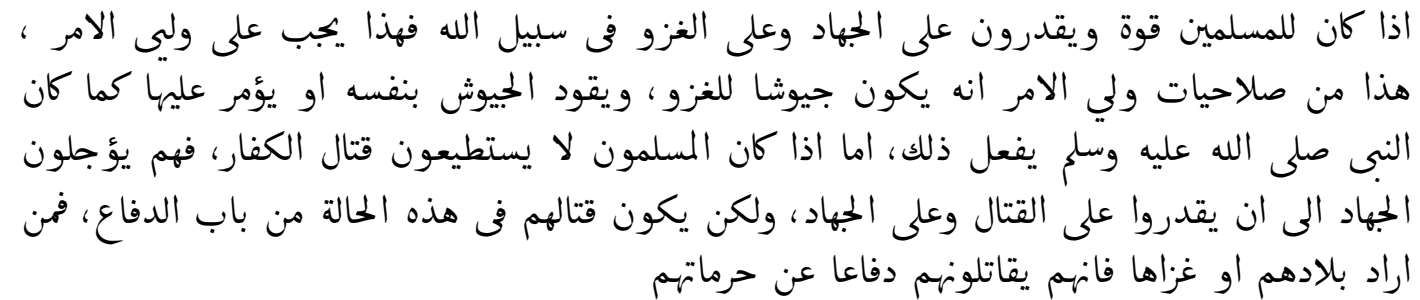

"If Muslims have the power and can wage jihād and invade in Allah's name, then this is a must on the ruler. It is within the authorities of the ruler to form armies for invasion. He leads the armies himself or delegates to a leader, as the Prophet (peace and blessings of Allah be upon him) did. If Muslims are unable to fight the infidels, they postpone the jihäd until they can fight, but their fight in this case should remain for defense, they fight whoever wants their country or conquers it, in defense of their sanctity. But if they have power, then they wage a Seeking (of the infidels) fight to spread Islam.

Al-fawzan's answer suggests that Muslims have a duty to wage offensive jihād and invade whenever they have the ability and power to do so. The only reason for postponing jihād is the lack of power or preparedness. While the spread of Islam is cited as the driving force, the only relevant characteristic of the enemy is being "infidel".

Additionally, fifty two Saudi salafi scholars called for jihād, mobilization, and unity to overthrow Bashar Al-Assad's regime, while the Council of Senior Scholars, headed by the Grand Mufti of the Kingdom, Sheikh 'Abd al-'Aziz Bin 'Abd Allah Al-Sheikh, called on "the Muslim nation" to do all they can to support "the oppressed and the mujāhidīn [jihādis] in Syria" (Alkhaleejonline 2015, October 6). The statement and description "oppressed" invoke a verse which was revealed to the Prophet giving him permission to wage jihād because Muslims were oppressed (The Noble Qurān 22: 39). Jihād needs to have a moral and religious justification, and by invoking a Qurānic text militancy becomes an act of religious allegiance.

\section{Conclusions}

The traditionalist salafis' online literature on Jihäd makes the case for militancy, theologically and intellectually. Scholars, preachers, and clerics alike are proactive on the media jihād front through preaching, teaching, and advice using the strategy of "jihād by the tongue and advocacy". Highly charged fatwas are issued by elites and volunteer clerics to promote and normalize militant jih $\bar{a} d$ as a duty on Muslims and the alternative vehicle for change. Islam is presented as the driving force, goal, and legitimizing authority, while preachers portray themselves as pious expert agents whose role is to explain, clarify, and advice on the best ways to perform the holy war of $j i h \bar{a} d$, its types, rewards, and list of Qurānic verses that endorse their fatwas. A variety of techniques are employed by this faction to justify militancy, including the focus on this sense of the concept of jihad, the use of selective citations from the Qurān, the abrogation of verses, and seeking justification from the ijtihād and ijm $\bar{a}^{\top}$ of medieval scholars. 
Islamic legal scholarship points out a range of meanings of jihād in the Qurān, extending from a Muslim's struggle to maintain their faith and observe Islamic practices to offering support to the disadvantaged by striving to overcome economic hardship (Kassam et al. 2018). However, the concept underwent a process of evolution because early Muslim scholars prioritized the meaning of a holy war with a view to securing the survival of the religious community and the protection of their land against external threat (Afsaruddin 2019). The medieval scholar Ibn Taymiyyah extended the target of this holy war to include both external and domestic oppressors and tyranny (al-bugiat $)$ (Kassam et al. 2018). The traditionalist salafis appear to have embraced this narrow sense of jihād unequivocally, and their reverence for Ibn Taymiyyah has earned him the title of Sheikh al-Islām (the Sheikh of Islam). While the "verse of the sword" has often been cited to justify militancy and violence, the word "sword" (سيف) has never been mentioned in the Quran and it was only at a later stage of the Islamic history that the said verse was named as such.

Early jurists and scholars of the past provided divergent rulings which repealed Qurānic texts when they stumbled on what they believed were irreconcilable Qurānic verses. In the absence of a text from Islam's primary sources giving authority or guidance to religious authorities to take the liberty and repeal texts, there has been disparity in opinion on the scope and number of abrogated texts.

The traditionalist salafis' argumentation and discourse on militant jihād draws on the ijtihād, or opinion, and 'ijmä', or consensus, of the esteemed "pious ancestors" and scholars of the past, allowing the abrogation of the Meccan verses which commanded forgiveness and peace with non-Muslims who do not fight Muslims. The abrogation of Qurānic texts is justified as a binding act of uniformity with the consensus of the scholars of the past and the ancestors. This opportunistic subservience to the opinion of the ancestors has given rise to competing narratives and fatwas that are constructed to invigorate militancy under the pretext of fighting "in the name of Allah" and in the footsteps of the "Prophetic methodology". The abrogation of the Meccan verses scaled down the Prophetic methodology by rendering over a decade of its early history as void. This subsequently bolstered the significance of the Medinan experience, which was characterized by religious wars, rivalry, and hostility. The traditionalist salafis' guidance leaves followers with no option or purpose in life other than militancy "on the path of Allah" (fì sabìl Alläh).

The unequivocal embrace of abrogation is inconsistent with the traditionalist salafis' creed at different levels. First, it reverses the power relationship between divinity and humans by subjecting God's word to the scrutiny, opinion, and political agendas of scholars. Second, it raises serious questions about the Qurān's unique quality of $i^{\prime} j a z$ ("inimitability"), which authenticates the Prophetic status of Muhammad (PBUH) and proves the superiority and perfection of the word of God. Third, it could implicitly suggest that God corrected Himself by replacing the abrogated texts with the abrogating ones. These points and the above discussion on abrogating the Meccan verses prove a level of pragmatism on the part of the traditionalist salafis in that they do not hesitate in employing methods which are not totally compatible with their creed and claim to authenticity if/when they are congruous with their political strategy. The focus on militant Jihād serves their political and military ambitions regionally, and the strategy then has to steer the religious arguments and selection of evidence.

From this perspective, the rulings of the ancestors and scholars of the past cannot be repealed because once a consensus has been reached, further ijtihād is not allowed. Ironically, the ijtihād and ' $i j m \bar{a}$ ' of scholars of the past have repealed divine texts, but the uniformity of the successive scholars' verdicts has consolidated their rulings to the extent that they have become immune to abrogation. It is justifiable to conclude that traditionalist salafis' channel their understanding and interpretation of the divine texts through the rulings of early Muslim scholars. In doing so, they authenticate but also severely constrain their own ability to exercise ijtihād and engage intellectually with the Qurānic texts and their interpretation within the current reality. The practice constitutes an insurmountable procedural hurdle that gives permanence to the rulings of the scholars of the past in favor of militant jihād. This reminds us of Schacht's (1964) comment that the gradual accumulation of a consensus seemed to suggest that no scholar could any longer be considered sufficiently equipped for new ijtihād 
in Islamic religious law. He concluded that subsequent religious activity had, therefore, been limited to the clarification and implementation of the teachings of Islam by reference to the established consensus.

Funding: This research received no external funding.

Conflicts of Interest: The author declares no conflict of interest.

\section{References}

Afsaruddin, Asma. 2019. Jihad. Encyclopædia Britannica. Available online: https://www.britannica.com/topic/ jihad (accessed on 26 April 2019).

Al Al-Sheikh, Sāliḥ 'Abd al-'Aziz. 2009. I'jāz al-Qurān (The Inimitability of the Quran) [Web log post]. Available online: http://www.kulalsalafiyeen.com/vb/showthread.php?t=3162 (accessed on 20 April 2019).

Al-Albāni, Muḥammad Nāsir Al-Dīn. 2004. Naṣịhat al-shaihn al-' Albānī li-'Abd al-Rimān 'abd al-hāaliq wa al-kalām 'alā al-taḩazzub wa al-takattul fī al-Kuwait (The Advice of Sheikh Al-Albani to Abd Al-Rahman Abd Al-Khaliq and Talking about Forming Parties and Factions in Kuwait) [Web log post]. Available online: http:// www.alathar.net/home/esound/index.php?op=tadevi\&id=143\&coid=1613 (accessed on 30 September 2018).

Al-'Ansi, Muhammad Al-Mawlid. 2017. Al-jihādu fĩ sabīli Allāh tijāratu al-mu 'min al-rābiḥa [Web log post], The Association of Yemeni Scholars. Available online: http://yemenscholars.com/articles/763 (accessed on 23 August 2018).

Al-Baghdādī, Abū Bakr. 2014. 'Abū Bakr al-Bag̉dādī yaḥtub al-jum'a bi al-Mosul wa-yaṭlub tāàatahu [Video post]. Available online: http://www.aljazeera.net/news/arabic/2014/7/5/الجمعة-بالموصل-ويطلب_طاعنه أبو-بكر _البغادي-يخطب (accessed on 1 October 2018). (The video can be accessed by pasting the Arabic text of the URL into a browser's address bar).

Al-Banna, Jamāl. 2011. Refuting the Allegation of Abrogation in the Holy Quran. Cairo: Dar El Shrouk Publishing Group.

Al-Fawzān, Sāliḥ. 2010. Ba'ḍ Aḥkām al-jihād li-l-mashāyihn [Web log post]. Available online: https://www.ajurry. $\mathrm{com} / \mathrm{vb} /$ showthread.php?t=10797 (accessed on 12 October 2018).

Al-Fawzān, Sāliḥ. n.d. Al-Muzāharāt wa al- 'i'tișāmāt Laysat min 'amal al-Muslimīn wa-lā 'urifat fì ta 'rīh al- islām wa-hiya faw d̦ā [Web log post]. Available online: http://ar.alnahj.net/audio/556 (accessed on 11 October 2018).

Al-Kalbāni, 'ādel. 2016. Imam of Mecca: ISIS are Salafi Like Us. Medina Minds [Video post]. Available online: https://www.medinaminds.com/imam-of-mecca-isis-are-salafi-like-us/ (accessed on 18 September 2018).

Alkhaleejonline. 2015. Siyāsat hay'at kibār al-'ulamā' al-sa'ūdiyya tad'ū li-nuṣrat sūriyā Bishatta al-subul. Alkhaleejonline Website. Available online: http://alkhaleejonline.net/السعودية-تندو -لنصرة-سوريا-بشتى_السبلسياسة/هيئة-كبار -العلماء (accessed on 10 August 2018).

Al-Khamīs, 'Othmān. 2011. Hal qatlu al-qadeāfī jā'iz? ('Is the Killing of al-Gaddāfi Permitted?') [Video post], Almanhaj TV channel. Available online: https://www.youtube.com/watch?v=5ByG-z2XU9g (accessed on 22 September 2018).

Al-Khuḍairi, Muhammad. n.d. Al-suwar 1-Makkiyya wa-l-Madaniyya. Available online: http://www.alsalafway. $\mathrm{com} / \mathrm{cms} /$ multimedia.php?action=text\&id=1033 (accessed on 18 September 2018).

Al-Munajjid, Muḥammad Saaliḥ. 2008. Ilm al-Makki wa al-Madani Min Suwar al-Quran al-Karim. Available online: https://islamqa.info/ar/answers/113148/علم_الككي-والمدني-من-سور -القران-الكريم (accessed on 15 November 2018).

Al-Najdiy, Hammām. 2012. Dawāfi' Jihād al-țalab fī al- islām wa-'illat Qatl al-kuffār wa-Muqātalatihim. Available online: https://www.ahlalhdeeth.com/vb/showthread.php?t=296234 (accessed on 12 November 2018).

Bedgali, Muḥammad, Niya Izzat Allah, and Godarzi Muḥammad. 2017. 'Inkāru al-nash fị l-qurān al-karīm [Web log post]. Available online: http://nosos.net/إنكار-النَّنْ-في_القرآن-الكريم// (accessed on 16 November 2018).

Bligh, Alexander. 1985. The Saudi Religious Elite (Ulama) as Participant in the Political System of the Kingdom. International Journal of Middle East Studies 17: 37-50. Available online: https://www.cambridge. org/core/journals/international-journal-of-middle-east-studies/article/saudi-religious-elite-ulama-asparticipant-in-the-political-system-of-the-kingdom/8CC8E501168D8B9B88CC934ED73D1BFD (accessed on 12 November 2018). [CrossRef] 
Cambridge Dictionary. n.d. Available online: https://dictionary.cambridge.org/dictionary/english/jihad (accessed on 26 April 2019).

Cummins, David. 2017. Arab Salafism. Oxford Bibiliographies. Available online: http://www.oxfordbibliographies. com/abstract/document/obo-9780195390155/obo-9780195390155-0139.xml?rskey=wPIuhl\&result=23 (accessed on 10 October 2018).

Esposito, John L., ed. n.d.a. Ijma. In The Oxford Dictionary of Islam. Oxford: Oxford Islamic Studies Online, Available online: http://www.oxfordislamicstudies.com/article/opr/t125/e989 (accessed on 10 November 2018).

Esposito, John L., ed. n.d.b. Ijtihad. In The Oxford Dictionary of Islam. Oxford: Oxford Islamic Studies Online, Available online: http://www.oxfordislamicstudies.com/article/opr/t125/e990 (accessed on 10 November 2018).

Hassan, Hassan. 2016. The Sectarianism of the Islamic State: Ideological Roots and Political Context. Carnegie Endowment for International Peace. Available online: https://carnegieendowment.org/ 2016/06/13/sectarianism-of-islamic-state-ideological-roots-and-political-context-pub-63746 (accessed on 10 September 2018).

Hjarvard, Stig. 2016. Mediatization and the Changing Authority of Religion. Media, Culture and Society 38: 8-17. Available online: https://journals.sagepub.com/doi/abs/10.1177/0163443715615412?journalCode=mcsa (accessed on 15 December 2018). [CrossRef]

Ibn Bāz, A. A. 1990. Naqd al-Qawmiyya al-'arabiyya fii ḍaw'al-Islām wa-al-wāqi' (Criticism of Pan-Arab Nationalism in the Light of Islam and the Reality). Available online: https://d1.islamhouse.com/data/ar/ih_ books/single/ar_nqd_alqwmih_alarbih.pdf (accessed on 13 September 2018).

Ibn Bāz, 'Abd al-'Aziz. n.d.a Laysa al-Jihād li-l-difā9 faqat ('jihād is Not Only for Defence') [Web log post]. Available online: https://binbaz.org.sa/old/32607 (accessed on 20 September 2018).

Ibn Bāz, 'Abd al-'Aziz. n.d.b Ma'nā Al-Islām (The meaning of Islām) [Web log post]. Available online: https://binbaz.org.sa/fatwas/14565/الاسلام: معنى (accessed on 20 April 2019).

Islam Q\&A. 2012. Revelation All at Once or Gradually? Available online: https://islamqa.info/en/180883 (accessed on 15 October 2018).

Islam Q\&A. 2015. Al-Nash fi al-Quran țābit bi al-Kitāb wa al-sunnah Wa al- 'ijmā'. Available online: https: //islamqa.info/ar/228722 (accessed on 19 October 2018).

Islamweb. 2002. Abrogated Verses of the Quran. Available online: http://www.islamweb.net/emainpage/index. php?page=showfatwa\&Option=FatwaId \&Id=84587 (accessed on 13 September 2018).

Islamweb. 2016. Al-nāsih wa al-mansūh̄ fī al-qurān. Available online: http://articles.islamweb.net/media/index. php?page $=$ article\&lang $=$ A\&id $=17291$ (accessed on 15 September 2018).

Jones, Seth G. 2014. A Persistent Threat: The Evolution of al Qa'ida and Other Salafi Jihadists. Publication of the Rand Corporation. Available online: https:/www.rand.org/content/dam/rand/pubs/research_reports/RR600/ RR637/RAND_RR637.pdf (accessed on 27 April 2019).

Kassam, Zayn, Greenberg Yudit Kornberg, and Bagli Jenan. 2018. Islam, Judaism, and Zoroastrianism. Netherlands: Springer.

Lauzieri, Henri. 2010. The Construction of Salafiyya: Reconsidering Salafism from the Perspective of Conceptual History. International Journal of Middle Eastern Studies 42: 369-89. Available online: https://www.jstor.org/ stable/40784818?read-now=1\&seq=2\#page_scan_tab_contents (accessed on 24 April 2019). [CrossRef]

Nielsen, Richard A. 2016. The Changing Face of Islamic Authority in the Middle East. Publication of the Crown Centre for Middle East Studies, Brandeis University. Available online: http://www.mit.edu/ \{\}rnielsen/ MEB99.pdf (accessed on 22 August 2018).

Olidort, Jacob. 2016. Does ISIS Really Follow the Salafi Version of Islamic Law and Theology? Publication of The Washington Institute. Available online: https://www.washingtoninstitute.org/policy-analysis/view/does-isisreally-follow-the-salafi-version-of-islamic-law-and-theology (accessed on 12 August 2018).

Saada, Najwan. 2018. The Theology of Islamic Education from Salafi and Liberal Perspectives. Religious Education 113: 406-18. [CrossRef]

Schacht, Joseph. 1964. An Introduction to Islamic Law. Oxford: Oxford University Press.

The Noble Qurān. n.d. Available online: http://www.thenoblequran.com/q/ (accessed on 15 August 2018).

Wagemakers, Joas. 2016. Salafism. Religion: Oxford Research Encyclopedias. Available online: http://oxfordre. com/religion/view/10.1093/acrefore/9780199340378.001.0001/acrefore-9780199340378-e-255 (accessed on 19 September 2018). 
Wiktorowicz, Quintan. 2006. Anatomy of the Salafi Movement. Studies in Conflict and Terrorism 29: $207-39$. Available online: https://www.tandfonline.com/doi/abs/10.1080/10576100500497004 (accessed on 2 June 2018). [CrossRef] 